\title{
Competition as a Savings Incentive: A Field Experiment at a Homeless Shelter
}

\author{
Sera Linardi* \\ University of Pittsburgh \\ Tomomi Tanaka\# \\ Arizona State University
}

\begin{abstract}
This paper describes a randomized field experiment testing the impact of a savings competition on the behavior of homeless individuals staying at a transitional shelter. When monetary prizes were offered for achieving the highest saving rates within a particular month, savings increased while income and attendance at case management meetings remained unchanged. However, repeating the competition in the following month had no effect. This is because individuals who increased their savings rate in response to the competition left the shelter after the first month. In general, while income is positively correlated with continued stay at the shelter, saving at high rates appears to predict early exit.
\end{abstract}

Keywords: field experiment, savings, income, competition, poverty, social services, homelessness, time inconsistency, participation

\section{JEL Codes: C93, D91, I3, J1, L3}

* Corresponding author. Graduate School of Public and International Affairs. 3203 Wesley W. Posvar Hall, 230 South Bouquet Street, Pittsburgh, Pennsylvania 15260. Phone: (412) 648-7650. Fax: (412) 648-7641 Email: linardi@pitt.edu

\# School of Politics and Global Studies. P.O. Box 873902, Tempe, AZ 85287-3902. Phone: (480) 727-0948 Fax: (480) 965-3929. Email: tomomi.tanaka@asu.edu 


\section{Introduction}

With 643,067 individuals homeless on any given night in the United States and potentially millions more at the brink, the goal of ending homelessness has become a prominent part of the Unites States' national agenda in recent years. ${ }^{1}$ For many people in the lowest income bracket, falling out of mainstream society can be surprisingly easy in contrast to the effort it takes to reintegrate. Unexpected job loss, a divorce, an addiction, a temporarily debilitating illness, or an arrest may result in a permanent alteration of a person's economic trajectory (O’Flaherty 2009a). In an attempt to reverse or halt this downward spiral, most homeless shelters provide not only material and legal support, but also life-skills programs specifically focused on employment and financial management (O’Flaherty 2009b). In order to help the homeless move out of shelters and into sustainable long term housing, it is crucial to provide a support structure that allows individuals to acquire financial responsibility and savings habits. ${ }^{2}$ However, the unique challenges faced by the very poor often lead to sporadic participation and noncompliance to program rules. Clients' inability or unwillingness to fully utilize the programs they have enrolled in represents a large opportunity cost both for the resource constrained social services sector and for the clients themselves.

This paper explores how insights from behavioral economics can be utilized to encourage homeless individuals to participate in a financial management programs and increase saving. We design and conduct a savings competition at a transitional homeless shelter in which participants have to commit to save, and those participants who achieve the highest saving rates receive monetary rewards.

\footnotetext{
${ }^{1}$ Recent research shows that from 2009 to 2011 there has been a 13\% increase in multifamily households and a $22 \%$ increase in families below the poverty line who are paying $50 \%$ or more of their income on housing; see "The State of Homelessness in America Report Suggests Risk of Homelessness Persists for Many American Families.” National Alliance to End Homeless Press Release, 17 January 2012. http://www.endhomelessness.org/content/article/detail/4358, accessed May 2012. President Obama provided $\$ 1.5$ billion in funding for homeless prevention in the American Recovery and Reinvestment Act of 2009; see http://www.hudhre.info/index.cfm?do=viewHprpProgram, accessed January 2012. Former President Bush had also made ending chronic homelessness a top objective in his 2003 budget.

${ }^{2}$ Why is savings important? It helps the newly housed weather shocks that could otherwise precipitate a return to homelessness. Savings is also an asset development approach, which has been shown to be more sustainable than income transfers (McKernan \& Sherraden 2008) and may also alter an individual's outlook to be more future-oriented (Oysterman and Destin 2010).
} 
A growing body of empirical literature has established the link between time inconsistency problems and poor financial outcomes. ${ }^{3}$ Commitment devices are widely proposed as the solution for time inconsistent individuals who are struggling to achieve their saving goals (Ashraf, Karlan and Yin 2006, Karlan 2010). Transition shelters typically offer two types of services that function as commitment devices. These services anticipate the difficulty that newly employed clients might experience in keeping their jobs and saving their income. The first is case management, which provides feedback about clients' employment and finances. The second is a savings program that can only be withdrawn upon clients' departure from the shelter. Unfortunately, take up on these devices is low: for instance, in our partner shelter more than $30 \%$ of the working homeless population did not attend a single case management meeting and less than $50 \%$ reported any savings.

Brocas and Carillo (2001) suggest another way to aid dynamically inconsistent individuals. Their theoretical model proposes that when time inconsistent individuals are placed in a competition, the probability of not being a winner increases the cost of procrastination and induces individuals to complete projects earlier. ${ }^{4}$ If procrastination is a contributing factor to the lack of savings, a savings competition may induce shelter clients to start saving earlier and thus leave the shelter with a larger financial safety net. ${ }^{5}$

To test the effect of competition on savings, we implemented a randomized experiment, which awarded the contestant who saved the highest percentage of his or her one-month income with $\$ 100 .{ }^{6}$ We find that for one month of competition, average savings increased by $\$ 80$ in the competition group. Since we did not observe an increase

\footnotetext{
${ }^{3}$ For example Harrison et al. 2002; Hausman 1979; Lawrance 1991; Nielsen 2001; Pender 1996; Tanaka et al. 2010; Yesuf 2004, Meier and Sprenger (2010).

${ }^{4}$ This is in marked contrast with standard theory of time consistent discounting, in which agents may be individually impaired by competition.

${ }^{5}$ Kremer, Miguel and Thornton (2009) find that merit scholarship programs enhanced scores; this was true even among those who are unlikely to win the competition. Experimental evidence from Tran and Zeckhauser (2008) indicates that competition for both social and monetary rewards improve the performance of Vietnamese students. The effect of competition on performance is enhanced when contestants are homogenous. Schotter and Weigelt (1992), Harbring and Irlenbusch (2008), and Muller and Schotter (2009) show that when some contestants have significantly higher ability, those with lesser ability will give up at the start of competition. For homeless individuals, a saving competition at the homeless shelter may be a rare opportunity to participate in a financial competition in which they have the same chance at winning as other contestants.

${ }^{6}$ Providing a monetary prize for the highest savings has an effect of lowering the expected prize of savings. Our savings competition therefore tests the combined effect of competition and of an expected savings subsidy. The number and \$ amounts of prizes are determined in partnership with shelter management.
} 
in total income, the observed increase in savings is a result of a direct decrease in expenditures. We find that the effect of competition is only at the intensive margin of savings. Shelter clients in the competition group are neither more likely to save nor report an income nor attend case management meetings.

We find no evidence that the competition has an effect when it is repeated in the following month. The data suggests that this is due to the fact that those who were saving the most during the first month of the competition left the shelter after the competition was completed. It appears that saving at a high rate predicts future disengagement from the shelter even outside of the competition setting. This is consistent with two very different explanations: ego depletion and self-selection. The first suggests that clients are exhausted by the effort of saving at high rates and stop investing further effort in shelter programs. ${ }^{7}$ The second suggests that individuals who are motivated to increase savings to win the competition are those who want to exit the shelter sooner. We leave this important question to future research.

This paper makes two contributions to the existing literature. As far as we know, this is the first paper that provides a detailed look of the saving behavior of working homeless and their transition out of the shelter. A better understanding of this population may not only provide clues to the seemingly intractable problem of chronic homelessness (O'Flaherty 2009c), but may also provide new insights about how the very poor reintegrate into the economic mainstream. This paper also contributes to the behavioral economics literature by showing that while a savings competition can indeed increase average savings in the short run, its effect may be limited to the intensive margin and may diminish with repetition. In general, it appears that policies that focus on savings incentives may be premature for this population. A more positive impact might come from interventions that stress capacity building, such as helping clients retain and progress at their jobs while simultaneously developing new income generating skills.

The paper is organized as follows. Section 2 describes the experimental design and the field setting. Section 3 describes the subject pool. In Section 4, we discuss the

\footnotetext{
${ }^{7}$ Those who saved at high rates in the past are more likely to stop attending case management meetings and/or earn income in the future. This observation fits with patterns of behavior attributed to exhaustion of will power such as weight gain after dieting (Neumark-Sztainer et al, 2012) and decreased performance in mental tasks after resisting temptation (Ozdenoren, Salant, and Silverman 2006).
} 
results of the experiment in four sections: the time discounting experiment (4.1), the first month of the saving competition (4.2), and lastly, the second month of the saving competition (4.3) where we discuss why repeating the competition has no effect. Section 5 concludes.

\section{Experimental Design and Setting}

As the largest homeless shelter in Arizona, Central Arizona Shelter Services (CASS) provides accommodation for up to six months to 415 adult men and women who are experiencing homelessness. As a transitional shelter, CASS's goal is to help these individuals regain the ability to sustain permanent housing. For this purpose, clients are provided with shelter, meals, access to donated personal items such as clothing and toiletries, and a full range of services such as legal aid, medical treatments, and case management.

As clients receive necessary counseling and training, they graduate through various levels at the shelter. Each level rewards clients with additional privacy and comfort in their living arrangement, but also brings with it additional requirements and responsibilities. Level III represents the highest level of readiness before clients graduate from the shelter into permanent housing. Individuals must provide proof of employment in order to move up to Level III. Many of the jobs that clients are able to obtain are commission based sales job or event-based contracts, which do not guarantee a steady income. $^{8}$

Clients in Level III are assigned a case manager and are required to meet with their case managers every two weeks so that their job progress may be monitored. They are also given the opportunity to participate in a savings program. During their case management meetings, clients are supposed to report their income, work related expenditures, and savings. ${ }^{9}$ This is done either by turning in paystubs, receipts of purchases, ATM receipts, or by bringing cash to save and then depositing it directly in

\footnotetext{
${ }^{8}$ For example shelter clients may be hired as telemarketers or to do set-up/tear-down at fairs or concerts. Individuals are not promptly removed from Level III if they lose their jobs.

${ }^{9}$ As mentioned in the introduction, the category of work related expenditure is a gray area. Though we do not have access to the clients' records, case managers indicated that clients have reported personal items, transportation costs, meals out, and cell phones in this list. Whenever applicable case managers also subtract fixed expenses such as existing debt and child support payments when calculating net income.
} 
the case manager's lockbox. Shelter rules indicate that Level III clients must report an income every two weeks and save $70 \%$ of their net income, which is calculated as income minus work related and fixed expenditures. ${ }^{10}$ Though documentation is required for all financial information, the incentive to overreport work expenditures and underreport income has always been present at the shelter.

Clients who do not follow shelter rules are supposed to be evicted after three warnings; however, in practice, enforcement is problematic, leading to a situation where compliance is optional. Our initial data collection at CASS, which we will refer to as Wave 0, provides data about the financial situation of 51 Level III subjects who had been employed for 1.5 months prior to the start of the study. Figure A1 in the Appendix shows that $30 \%$ had yet to attend a single case management meeting and thus had no recorded financial information. ${ }^{11}$ An additional $10 \%$ met with the case manager but reported no income. Among those who reported an income, the average income was $\$ 23 /$ day and the average savings was $\$ 6.3$ / day, resulting in a $28 \%$ savings rate.

Based on the financial information of clients in Wave 0, it is clear that the subject pool was capable of significantly increasing their monthly savings. In a survey of Level III clients that asked clients what they needed to do to get out of homelessness, the most common responses were: save more (89\%), acquire additional education (84\%), reconcile with family (48\%), and recover from addiction (32\%). ${ }^{12}$ This survey information indicates that saving more is not just the shelter's goal, but one shared by the participants as well.

The intervention to increase savings was implemented in close partnership with shelter management in three additional data collection periods, which we will refer to as Waves 1-3. A major appeal of competition is cost effectiveness since it can potentially

\footnotetext{
${ }^{10}$ Computing exact savings rate is difficult because some clients report savings larger than income, which suggests that they earned money from unreported sources (i.e. selling blood, panhandling, collecting debts). At the same time, others withdraw savings in violation of shelter rules, resulting in negative savings rates. However, these numbers are small: only 3 of the 35 individuals in the control group and 8 out of 66 in the monetary group have savings rate less than 0 or greater than 1 .

${ }^{11}$ Even though it is possible that those who do not attend case management have an income and are hiding it, shelter staff believes that the majority of clients that do not attend case management have not earned any income or have lost their jobs. We treat income and savings of subjects who never attended meetings as $\$ 0$ in our summary statistics (Figures A1, A2 and Table 4) and as missing in Tables 5, 6, A3, and A4.

${ }^{12}$ We were able to conduct the survey on subject goals with the first and last wave of subjects (Wave 0 and Wave 3). The low rate of participants that reported needing help with addiction may be due to the fact that those with serious addiction problems are unlikely to graduate to Level III.
} 
affect the behavior of many, while only providing a single payout. It can also be readily embedded within the existing structure of case management. ${ }^{13}$ The shelter required that clients compete to achieve the highest savings rate rather than for the absolute highest amount of savings due to differences in income earning ability.

Shelter management was also concerned that our initial design of a one-time competition with a single $\$ 100$ prize did not provide sufficient opportunity for clients to win. We made two modifications to accommodate their concerns. First, additional prizes were offered in each wave. ${ }^{14}$ However, our fundamental treatment remained a \$100 reward to the person who saved at the highest rate. We control for the difference in prizes across waves in the data analysis through wave fixed effects. ${ }^{15}$ The second modification is that we allowed subjects to automatically re-enroll for a second month of competition. However, after observing that offering a second month of competition did not result in higher client retention in Wave 1 and Wave 2, the shelter agreed to return to one month competitions. We analyze Wave 1 and Wave 2 separately in Section 4.2 to understand how performance in the first month affects performance in the second month.

\section{Implementation}

To better understand the financial decision making of our subject pool, we preceded our policy experiment with a time discounting experiment. The time discounting experiment was conducted with 51 clients staying at the shelter from April to July of 2009; we refer to this group as Wave 0. The savings competition was conducted with 123 clients recruited from Wave 1 to 3, from October 2009 to May 2010. ${ }^{16}$ Subjects that agreed to participate in the savings competition threw a dice. Each participant had a

\footnotetext{
${ }^{13}$ Implementing a policy intervention independently of the case managers was not possible since visitors' access to shelter residents required case manager accompaniment for security reasons.

${ }^{14}$ A second place prize of $\$ 50$ was offered to participants in Wave 1 . A second and third place prize of $\$ 100$ was offered to participants in Wave 3. Wave 2 competitions were conducted in three groups of 5.

${ }^{15}$ If anything, the introduction of additional prizes should further increase performance. Moldavunu and Sela (2001), Schotter and Muller (2010) and Sheremeta (2010) show that tournaments with multiple prizes result in higher aggregate performance than winner-take-all tournaments.

${ }^{16}$ Each wave involves a different group of individuals since clients from the previous wave had already left the shelter by the time a new wave had started.
} 
$67 \%$ chance of being randomized into the competition group. In total we had 46 subjects in the control group and 77 subjects in the monetary competition group.

Table 1 Experimental Timeline

\begin{tabular}{|l|l|l|}
\hline Dates & Wave \#, number of clients & Experiment \\
\hline & & \\
$4 / 09-7 / 09$ & Wave $0(\mathrm{~N}=51)$ & Time discounting \\
$10 / 09-11 / 09$ & Wave $1(\mathrm{~B}=23, \mathrm{C}=37)$ & Saving: Month 1, Month 2 \\
$2 / 10-3 / 10$ & Wave 2 $(\mathrm{B}=11, \mathrm{C}=21)$ & Saving: Month 1, Month 2 \\
$4 / 10$ & Wave 3 $(\mathrm{B}=12, \mathrm{C}=19)$ & \\
& & \\
\hline Total & $\mathrm{N}=174$ & \\
Month 1 & $\mathrm{N}=123$ & \\
Month 1-2 & $\mathrm{N}=90$ & \\
\hline
\end{tabular}

Table 2 Demographic information, all subjects (N=174)

\begin{tabular}{|l|r|r|r|r|r|}
\hline & Mean & Std Dev & Min & Max & Base vs Comp pval \\
\hline Age & 41.18 & 11.26 & 19 & 70 & 0.45 \\
Female & 0.23 & 0.42 & 0 & 1 & 0.83 \\
Years of education & 12.17 & 2.22 & 0 & 19 & 0.59 \\
Never married & 0.57 & 0.5 & 0 & 1 & 0.36 \\
Children & 0.98 & 1.51 & 0 & 8 & 0.87 \\
White & 0.56 & 0.5 & 0 & 1 & 0.95 \\
Black & 0.31 & 0.46 & 0 & 1 & 0.43 \\
First time homeless & 0.5 & 0.5 & 0 & 1 & 0.91 \\
Length of homelessness & 12.41 & 20.41 & 0 & 204 & 0.80 \\
(months) & & & & & \\
\hline
\end{tabular}

Table 2 summarizes the characteristics of all 174 subjects from all four waves. Since all but one of the Level III clients agreed to participate, this also describes all the working homeless at the shelter during these periods. 23\% of the subjects are female and the average age is 41 years old. $57 \%$ of the subjects have never married and on average the subjects have one child. $56 \%$ of participants are white and $31 \%$ are black. ${ }^{17}$ Most of

\footnotetext{
${ }^{17}$ This racial composition is different from the typical homeless population in which $49 \%$ are black and $35 \%$ are white. This may be due to selection into Level III; see "Who Is Homeless?" Published by the National Coalition for the Homeless, July 2009. http://nationalhomeless.org/factsheets/who.html, Accessed May 2012.
} 
the subjects are high school graduates. Half of our subjects have never been homeless before. Including time spent at CASS, the average duration of homelessness is one year. However, the distribution of duration of homelessness is highly skewed to the right. The median subject has been homeless for only six months. The last column in Table 2 shows the p-value of a t-test comparing participants in the control and the monetary competition groups. The demographics of both groups are very similar to each other, suggesting that randomization was successful.

There are some notable differences across the waves. Subjects in Wave 0 are the only set of subjects that had been at the shelter before we started this study and consequently these subjects had been in Level III substantially longer than subjects in Waves 1-3. ${ }^{18}$ Subjects in Wave 1 had been in Level III for an average of 29 days before we recruited them to the competition. At the time of recruitment, less than $60 \%$ had participated in case management and only $40 \%$ had earned an income. ${ }^{19}$ Among those who had reported an income, the average income was $\$ 17.5 /$ day and the average savings was $\$ 10.7 /$ day. On average, the savings rate is $53 \% .{ }^{20}$ The lower income and lower rates of case management in Wave 1 as compared to Wave 0 can be explained by the relatively shorter period of employment for Wave 1. The increase in savings rate, however, suggests that the presence of researchers may have induced case managers to be more vigilant about encouraging all clients to meet the savings rate. Taking Wave 0 and Wave 1 together, the pre recruitment savings rate is $39 \%$.

No pre-recruitment case management information is available for clients from Wave 2 and 3. Clients in Wave 2 had technically been in Level III for as long as clients in Wave 1, but had entered during the low activity Christmas holiday season. ${ }^{21}$ Clients in Wave 3 clients were recruited immediately upon their arrival at Level III.

\section{Results}

\footnotetext{
${ }^{18}$ Wave 0 financial information is discussed in Section 2.

${ }^{19}$ See upper panel of Appendix Figure A2 for compliance rates in Wave 1. The bottom panel of Appendix Figure A2 illustrates income, savings, and work expenditure averaged across all subjects in Wave 1.

20 During the pre recruitment phase, two subjects in the control group earned no income, but reported savings averaging \$255. They are included in Figure A2, but excluded from the $53 \%$ average savings rate.

${ }^{21}$ In the December - January holiday period many clients and staff members are temporarily away from the shelter to visit with friends and family.
} 
We discuss the results of the experiment in four sections: the time discounting experiment in Wave 0 (4.1), the first month of the saving competition in Wave 1-3 (4.2), and the two months of repeated competition in Wave 1-2 (4.3).

\subsection{Time Discounting: Staying at Shelter for Financial Gain}

Time discounting is a fundamental preference that affects wealth accumulation. ${ }^{22}$ People are often time-inconsistent, i.e., they often place an especially high value on immediate consumption as compared to future consumption. ${ }^{23}$ Dynamic inconsistency can manifest in multiple ways at the shelter. Individuals may postpone case management meetings, invest too little effort in their jobs, save too little of their earned income, and/or leave the shelter before saving enough.

At present, little is known about how individuals who are staying at homeless shelters make financial decisions. To learn more about our subject pool, we preceded our policy experiment with a time discounting experiment. A brief description of the procedure is outlined below. The full questionnaire and a detailed description of the implementation can be found in the Experimental Appendix.

Fifty-one subjects who were staying at Level III during the summer of 2009 participated in the time discounting experiment. The experiment consists of a sequence of thirty-one questions. The questions are determined by previous choices in order to precisely pinpoint the number of days that render a subject indifferent between a smaller current payoff and a larger future payoff. ${ }^{24}$ At the end of the experiment, subjects

\footnotetext{
22 Eckel, Johnson and Montmarquette (2005) show that the results of short-horizon time discounting experiment explain long-horizon time preferences. Burks, Carpenter, Goette and Rustichini (2009) demonstrate that time discounting correlates with individuals' cognitive skills, which are also strongly correlated with job attainment.

${ }^{23}$ The citation below provides a sliver of this large and rich literature. See Strotz (1956), Phelps and Pollak (1968), Thaler (1981), Laibson (1997), O’Donoghue and Rabin (1999) for theoretical underpinnings of time inconsistency. Some recent empirical evidence from field studies can be seen in Ausubel (1999), Angeletos et al. (2001), Gross and Soules (2002), Ameriks, Caplin, Leahy and Tyler 2007), Skiba and Tobacman (2008), Agarwal, Skiba and Tobacman (2009), Carrell and Zinman (2008), Karlan and Zinman (2009) Zinman (2010), and Meier and Sprenger (2010).

${ }^{24}$ For example, suppose a subject is asked: “Do you want to receive $\$ 10$ today or $\$ 30$ in 64 days?” A subject who chooses $\$ 10$ today will be asked in the next question to choose between $\$ 10$ today and $\$ 30$ in 32 days, a 50\% reduction in the waiting period from the original 64 days. On the other hand, a subject who chooses to wait 64 days will be asked next to choose between $\$ 10$ today and $\$ 30$ in 96 days, a 50\% increase from 64 days.
} 
randomly draw a number between 1 and 31 to determine the question that will be used for experimental payments. In the presence of the subject, the experimenter places a money order in the amount of the subject's chosen payoff in an envelope marked with an ID and a pick-up date prior to sealing the envelope. Subjects are told to pick up the envelope at the appointed date from the case manager's office. ${ }^{25}$ Though subjects are free to leave the shelter and return to pick up rewards at a later date, subjects who are unwilling to return to the shelter may base their decisions to wait on their expected exit date; therefore our time discounting experiment should not be interpreted as a measure of innate preferences. Rather, it is a preliminary way to identify demographic characteristics and elements of past history that are likely to influence subjects' willingness to stay at the shelter for monetary rewards.

In Table 3 Model 1 we start our data analysis by estimating the discount rate (r) of the exponential time discounting model. In this model individuals weight consumption taking place $t$ days in the future by $\mathrm{e}^{-\mathrm{rt}}$. In Model 2 we continue with estimating $(\beta, \mathrm{r})$ in the quasi-hyperbolic discounting model (Laibson 1997) where $\beta$ denotes the present-bias parameter. Here agents place a weight of 1 on present rewards and a weight of $\beta \mathrm{e}^{-\mathrm{rt}}$ on rewards at time t. The probability of choosing the immediate reward \$x over the delayed reward \$y in t days can be represented by following logistic function:

$$
P(x>(y, t))=\frac{1}{1+\exp (-(x-y \beta \exp [-r t]))}
$$

We include control variables $\left(X_{i}\right)$ in the form of demographics in Model 3 and in the form of subjects' past history at the shelter in Model 4 . Models 3 and 4 estimate $\left(\beta_{0}, \mathrm{r}\right)$ from the equation $\beta=\beta_{0}+\sum \beta_{i} X_{i}$.

Model 1 estimates an r of 0.02 while Model 2 yields estimates of 0.003 for $\mathrm{r}$ and 0.40 for $\beta$. These estimates are well within the range of estimated parameters in previous studies. ${ }^{26}$ Demographic variables initially have little impact in Model 3 but became

\footnotetext{
${ }^{25}$ We chose to disburse experimental payments through case management because subjects indicated that they are most comfortable entrusting their money to the case managers. The envelopes are kept in a safe in the case manager's office and are available to the subject any time after the appointed date. The shelter requested us to give money orders instead of cash for security reasons.

${ }^{26}$ Beta is estimated to be 0.55 in Angeletos et al. (2001) and 0.64 in Tanaka, Camerer and Nguyen (2010). See Brown, Chua and Camerer (2009) for a review of quasi-hyperbolic parameter estimates. Our estimate of beta is smaller than other studies. Many studies linking discount rates to wealth show richer people
} 
significant in Model 4 after controlling for clients' history at the shelter. We find that subjects that are older (Age), have never been married (Single), have spent more time at the shelter (Days L1-2 and Days L3), and have been saving at high rates (Pre income and Pre saving) are unwilling to wait at the shelter for rewards. ${ }^{27}$ On the other hand those who are: African Americans (Black), homeless for the first time (First time), have been homeless longer (Mo. homeless), and are earning but not saving are willing to wait longer at the shelter. In Section 4.2 and 4.3 we see that many of these variables are correlated with observed behavior in the policy experiment.

Table 3 Time discounting results

\begin{tabular}{|c|c|c|c|c|}
\hline & Model 1 & Model 2 & Model 3 & Model 4 \\
\hline$r$ & $\begin{array}{c}0.02 \\
(0.00)^{* * *}\end{array}$ & $\begin{array}{l}0.003 \\
(0.00)^{* * *}\end{array}$ & $\begin{array}{l}0.002 \\
(0.00)^{* * *}\end{array}$ & $\begin{array}{c}0.005 \\
(0.00)^{* * *}\end{array}$ \\
\hline$\beta$ & & $\begin{array}{l}0.40 \\
(0.00)^{* * *}\end{array}$ & $\begin{array}{l}0.42 \\
(0.03)^{* * *}\end{array}$ & $\begin{array}{l}0.60 \\
(0.03)^{* * *}\end{array}$ \\
\hline Age & & & $\begin{array}{l}-0.82 \\
(0.54)\end{array}$ & $\begin{array}{l}-1.47 \\
(0.58) * *\end{array}$ \\
\hline Female & & & $\begin{array}{c}5.56 \\
(10.44)\end{array}$ & $\begin{array}{c}11.63 \\
(16.49)\end{array}$ \\
\hline Education & & & $\begin{array}{c}1.18 \\
(2.74)\end{array}$ & $\begin{array}{l}-3.28 \\
(2.93)\end{array}$ \\
\hline Single & & & $\begin{array}{l}-6.31 \\
(7.84)\end{array}$ & $\begin{array}{l}-18.24 \\
(10.51)^{*}\end{array}$ \\
\hline \# of children & & & $\begin{array}{l}-0.02 \\
(2.73)\end{array}$ & $\begin{array}{l}-5.63 \\
(4.07)\end{array}$ \\
\hline Black & & & $\begin{array}{c}1.57 \\
(9.14)\end{array}$ & $\begin{array}{l}24.75 \\
(10.41)^{* *}\end{array}$ \\
\hline First time & & & $\begin{array}{l}-1.70 \\
(9.15)\end{array}$ & $\begin{array}{l}19.03 \\
(11.15)^{*}\end{array}$ \\
\hline Mo homeless & & & $\begin{array}{c}0.51 \\
(0.19)^{* *}\end{array}$ & $\begin{array}{l}1.53 \\
(0.32)^{* * *}\end{array}$ \\
\hline Days L1-2 & & & & -0.38 \\
\hline
\end{tabular}

exhibit greater patience (Harrison et al. 2002; Hausman 1979; Lawrance 1991; Nielsen 2001; Pender 1996; Tanaka et al. 2010; Yesuf 2004). Our low estimate of beta may be due to a combination of the extreme poverty in our subject pool and the subjects' unwillingness to return to the shelter to pick up rewards.

${ }^{27}$ Days L1-2 indicates the number of days that a subject has spent in Levels I and II. Days L3 is the number of days that a subject has spent in Level III before the time discounting experiment. Pre income is income reported to case manager before the time discounting experiment (in units of \$100). Pre saving is saving reported before time discounting experiment (also in units of \$100). 
Note: For Model 3-4, $\beta$ is the intercept $\beta_{0}$ in Eq (1).

\subsection{Savings Competition : First Month}

The policy experiment took place between October of 2009 and May of 2010 in three waves, with a total of 123 subjects. Subjects in each wave rolled a dice to determine their assignment to the control or competition group. In each month, the individual in the competition group that saved the largest fraction of their net income was awarded $\$ 100 .^{28}$

Table 4 provides an initial summary of the results of the first month of competition. Competition is a dummy variable set to 1 for subjects assigned to the competition group. Model 1 shows that subjects report an average earning of \$240 during the first month of the competition (\$8/day). There is no increase in reported income due to the competition, which may be due to limited employment opportunities for this population. The constant in Model 2 shows that average savings in the control group was \$128 (\$4.26/day), while the Competition dummy indicates that the average savings among subjects in the competition group increased by $\$ 79.86$ (an extra $\$ 2.6 /$ day). Average savings rate in the control group was $53.5 \%$, while the average savings rate in the competition group was $83 \% .^{29}$

\footnotetext{
${ }^{28}$ Additional prizes are offered in each wave. See Section 3.

${ }^{29}$ Even though we have limited data to compare subjects' savings rate before and after randomization, it does not appear that those in the control group were discouraged from saving. First, recall that average pre recruitment savings rate from subjects in Waves 0 and 1 is $39 \%$, which is lower than the average savings rate in the control group. Furthermore, subjects in the control group of Wave 1 were saving $55 \%$ of their income before recruitment and $61 \%$ of their income during the first month of competition.
} 
The increase in savings is significant when we controlled for income (Model 3), indicating that the competition increased subjects’ savings rate. Model 4 and Model 5 suggest that subjects were not only saving funds that would fall under discretionary spending, but also funds previously claimed as work related expenditures.

Even though financial information was self-reported, the results in Table 4 suggest that subjects were not trying to win the competition through strategic manipulation of reports. Since savings rates are computed as the ratio of savings to net income (income less fixed and work related expenditure), subjects could achieve a higher rate of savings by strategically underreporting income and over-claiming their expenses as work expenditures. Instead subjects in the competition group reported an average increase of $\$ 32.6$ in their net income due to reductions in their work expenditures.

Table 4 First month finances, Wave 1-3

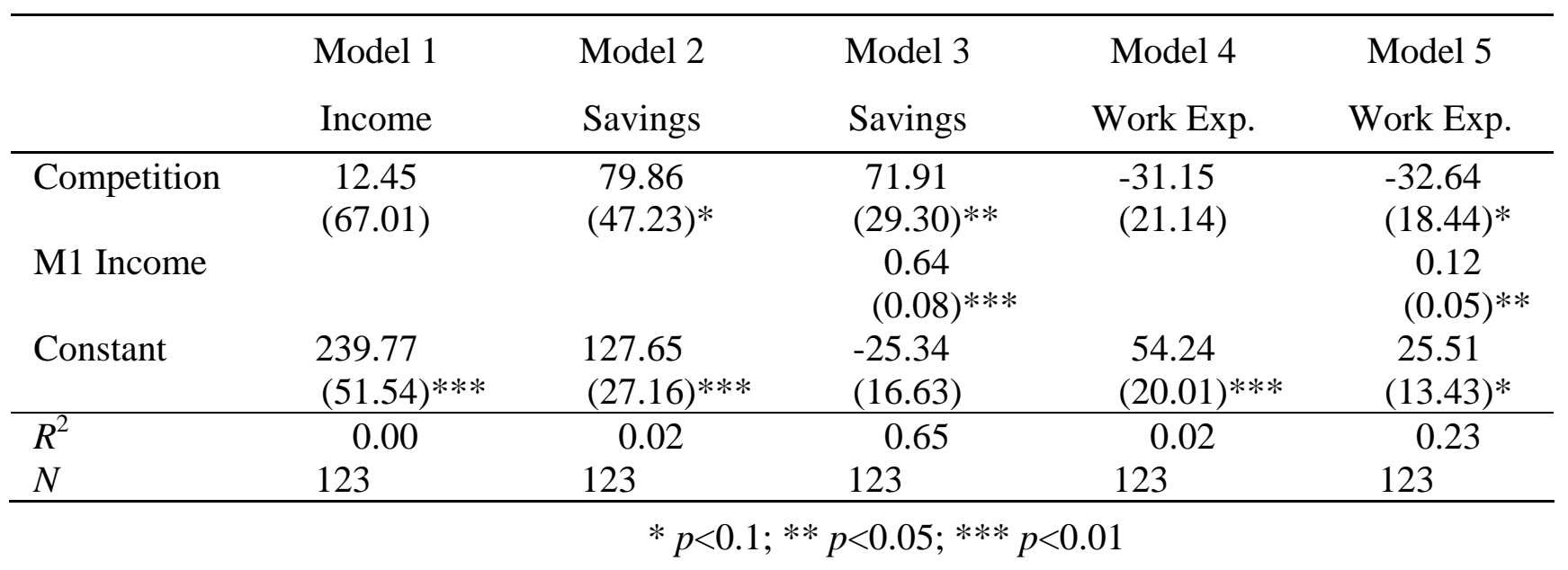

These results are robust after controlling for demographic characteristics, subjects' history at the shelter, and wave fixed effects (Table A1 in Appendix). Interestingly, many of the variables that are significant in the time discounting experiment are also significant predictors of first month behavior. Black subjects were saving at higher rates, while Single subjects were saving less. Older clients (Age) were more likely to earn a higher income, which may have led to more options outside of the 
shelter. ${ }^{30}$ However, being homeless for the first time (First time), the length of homelessness (Mo. homeless), and duration of stay in the shelter (Days L1-2 and Days L3), which were significant in the time discounting experiment do not predict financial behavior. For the sake of brevity, the regressions in the rest of the paper will include only the demographic variables Age, Single, and Black, in addition to income and savings reported before recruitment (Pre income and Pre savings). Note that Pre income and Pre savings are $\$ 0$ for subjects in Waves 2 and 3 since these subjects had not reported any income or savings at the start of the competition.

We now look more carefully into the impact of competition on subjects' behavior in the financial management program. We would like to answer the following questions: Are subjects in the competition group attending case management meetings more frequently? Does competition encourage clients to start earning an income? Is the impact of competition on savings coming from the intensive or the extensive margin?

A quick comparison of participation rates across the control and competition group suggests that competition may have a slight positive effect. Among the 46 subjects in the control group, $70 \%$ attended at least one case management meeting, $46 \%$ reported some income, and 39\% reported some savings. In the competition group these rates were $81 \%$, 56\%, and 51\%, respectively. Competition has no impact on savings at the extensive margin: more than $90 \%$ of subjects with an income reported positive savings regardless of treatment group.

The four regressions in Table 5 provide formal tests of the impact of competition on behavior in case management. Models 1 and 2 are OLS regressions restricted to subjects who reported any income. ${ }^{31}$ The dependent variable in Model 1 is the amount saved, while the dependent variable in Model 2 is the amount earned. Model 3 is a linear probability model. The dependent variable is a binary variable set to 1 if a subject reports an income; the regression is restricted to subjects who have met at least once with the

\footnotetext{
${ }^{30}$ There is a slight wage-saving correlation, but no wage-education correlation. For the highly educated, homelessness may have been caused by significant health, personal, or legal problems that negated the benefit of education.

${ }^{31}$ We exclude the probability of saving conditional on having reported an income from Table 5. As expected, given the $90 \%$ savings rate, the coefficient on Competition is not significant (pval=0.9). Results from Model 1 are robust when observations are further restricted to subjects with savings.
} 
case manager. Model 4 is an OLS regression on the number of case management meetings attended; all subjects are included in this regression.

Table 5 Effect of competition on behavior: Wave 1-3

\begin{tabular}{|c|c|c|c|c|}
\hline & $\begin{array}{c}\text { Model } 1 \\
\text { M1 Saving | M1 } \\
\text { Income >0 }\end{array}$ & $\begin{array}{c}\text { Model } 2 \\
\text { M1 Income | M1 } \\
\text { Income >0 }\end{array}$ & $\begin{array}{c}\text { Model } 3 \\
\text { Pr(M1 Income }>0 \text { | } \\
\text { M1 meeting }>0)\end{array}$ & $\begin{array}{l}\text { Model } 4 \\
\text { M1 Meeting }\end{array}$ \\
\hline Competition & $\begin{array}{c}133.87 \\
(50.04)^{* * *}\end{array}$ & $\begin{array}{r}-25.79 \\
(91.19)\end{array}$ & $\begin{array}{c}0.10 \\
(0.10)\end{array}$ & $\begin{array}{c}0.05 \\
(0.18)\end{array}$ \\
\hline Pre income & $\begin{array}{r}-41.18 \\
(25.42)\end{array}$ & $\begin{array}{l}52.51 \\
(43.57)\end{array}$ & $\begin{array}{c}0.02 \\
(0.03)\end{array}$ & $\begin{array}{l}0.19 \\
(0.07)^{* * *}\end{array}$ \\
\hline Pre saving & $\begin{array}{l}58.31 \\
(26.05)^{* *}\end{array}$ & $\begin{array}{r}-34.53 \\
(44.77)\end{array}$ & $\begin{array}{l}-0.01 \\
(0.04)\end{array}$ & $\begin{array}{l}-0.18 \\
(0.08)^{* *}\end{array}$ \\
\hline M1 meeting & $\begin{array}{l}73.36 \\
(49.34)\end{array}$ & $\begin{array}{l}80.29 \\
(56.88)\end{array}$ & $\begin{array}{c}0.15 \\
(0.09)\end{array}$ & \\
\hline M1 income & $\begin{array}{l}66.47 \\
(11.59)^{* * *}\end{array}$ & & & \\
\hline Age & $\begin{array}{l}-0.47 \\
(1.91)\end{array}$ & $\begin{array}{l}13.14 \\
(4.24)^{* * *}\end{array}$ & $\begin{array}{l}0.01 \\
(0.00)^{* * *}\end{array}$ & $\begin{array}{c}0.01 \\
(0.01)\end{array}$ \\
\hline Single & $\begin{array}{r}-65.56 \\
(47.52)\end{array}$ & $\begin{array}{r}-114.49 \\
(87.38)\end{array}$ & $\begin{array}{c}0.03 \\
(0.12)\end{array}$ & $\begin{array}{l}-0.14 \\
(0.18)\end{array}$ \\
\hline Black & $\begin{array}{l}185.68 \\
(82.00)^{* *}\end{array}$ & $\begin{array}{r}-49.78 \\
(78.23)\end{array}$ & $\begin{array}{c}0.07 \\
(0.12)\end{array}$ & $\begin{array}{l}-0.30 \\
(0.17)^{*}\end{array}$ \\
\hline Constant & $\begin{array}{r}-182.13 \\
(108.94)\end{array}$ & $\begin{array}{r}-259.24 \\
(264.83)\end{array}$ & $\begin{array}{l}-0.24 \\
(0.30)\end{array}$ & $\begin{array}{l}1.02 \\
(0.45)^{* *}\end{array}$ \\
\hline$R^{2}$ & 0.69 & 0.32 & 0.14 & 0.11 \\
\hline$N$ & 63 & 63 & 93 & 122 \\
\hline
\end{tabular}

All regressions include Wave fixed effect.

We find that the dummy variable Competition is only statistically significant in Model 1, suggesting that the only effect of the competition is to increase the savings rate of subjects with an income. ${ }^{32}$ The competition has no impact on either the amount of income earned or the propensity to earn any income. Competition also does not affect the frequency with which subjects attend case management meetings. The regression results indicate that the best predictor of propensity to save is income. Subjects in the control group were already saving at high rates: subjects saved $\$ 66.47$ of every $\$ 100$ earned. Older subjects are not only more likely to report an income, but they are also more likely

32 The results hold when Model 1 is restricted to subjects that reported savings. 
to report larger incomes than other subjects in the population. Black subjects attend case management less frequently, but those who do attend meetings and report an income save at a higher rate than other subjects.

Clients' behavior prior to recruitment is an important predictor of their behavior in the first month of the savings competition. Model 1 suggests that, conditional on earning an income in the first month, every $\$ 100$ saved prior to the competition (Pre saving) translated to \$58 saved during the first month. However, in Model 4 we find that Pre income has a positive impact on the number of case management meetings attended while Pre saving has a negative impact. This suggests that high rates of savings predict less engagement with shelter programs, which is consistent with the results of the earlier time discounting experiment.

\subsection{Savings Competition M2 (Second Month)}

We now turn our focus to the second month of savings. As previously discussed in Section 2, the one-month savings competition in Wave 1 and Wave 2 was immediately

repeated in the following month. ${ }^{33}$ Subjects' dice roll at the recruitment period before the first month of competition determines their assignment to both months of competition.

Month to month attrition rates at Level III are typically high, and the period of our study was no exception. Percentages of Wave 1 and 2 subjects who met at least twice with the case manager, reported a positive income, and saved in the first month were $75 \%, 47 \%$, and $44 \%$, respectively. In the second month, these percentages had fallen to $41 \%, 25 \%$, and $22 \%$.

Table 6 summarizes the second month results of the same four regressions reported in Table 5: Model 1 and Model 2 are OLS regressions restricted to subjects that are earning an income. The dependent variable on Model 1 is savings. The dependent variable in Model 2 is income. Model 3 is a linear probability regression on the likelihood of reporting an income in the second month. It is restricted to subjects that met with the

\footnotetext{
33 Table A3 in the appendix confirms that the results in Table 5 are robust when the data is restricted to only Waves 1 and 2.
} 
case manager at least once. Model 4 is an OLS regression on the number of case management meetings attended.

We see that Competition is never significant. In the second month, competition no longer increases the savings rate. As before, amount saved is primarily determined by income earned. Subjects saved an average of \$62 for every \$100 earned. Demographic variables have little predictive power in the second month. However, behavior in the previous month (M1) does influence behavior in the second month. The number of case management meetings attended in the previous month (M1 meet) is positively correlated with the amount saved in the second month (Model 1) and also the frequency of case management attendance (Model 4). In Model 3 the positive coefficient on M1 income and the negative coefficient on M1 saving imply that subjects that were saving at a high rate in the first month are less likely to report an income in the second month. This is consistent with earlier evidence reported in Tables 3 and 5, which correlates high rates of saving with early disengagement from shelter programs. We next investigate whether this linkage could be responsible for the ineffectiveness of the second month of competition.

Table 6 Impact of Competition in the $2^{\text {nd }}$ month

\begin{tabular}{lcccc}
\hline & $\begin{array}{c}\text { Model 1 } \\
\text { M2 Saving } \mid \text { M2 } \\
\text { Income>0 }\end{array}$ & $\begin{array}{c}\text { Model 2 } \\
\text { M2 Income } \mid \text { M2 } \\
\text { Income>0 }\end{array}$ & $\begin{array}{c}\text { Model 3 } \\
\text { Pr(M2 Income>0 | M2 } \\
\text { meeting>0) }\end{array}$ & Model 4 Meeting \\
\hline Competition & -197.67 & -94.06 & 0.20 & -0.11 \\
M1 meet & $(128.59)$ & $(296.36)$ & $(0.18)$ & $(0.18)$ \\
& 190.52 & -33.37 & 0.01 & 0.45 \\
M1 income & $(105.73)^{*}$ & $(251.08)$ & $(0.12)$ & $(0.10)^{* * *}$ \\
M1 saving & 20.27 & -47.64 & 0.08 & 0.02 \\
& $(37.02)$ & $(52.58)$ & $(0.03)^{* *}$ & $(0.05)$ \\
M2 meet & -95.36 & 109.83 & -0.10 & -0.04 \\
M2 income & $(80.52)$ & $(84.73)$ & $(0.05)^{*}$ & $(0.04)$ \\
Age & -41.31 & 196.36 & 0.32 & \\
& $(110.83)$ & $(183.03)$ & $(0.16)^{*}$ & \\
Single & 62.87 & & & 0.01 \\
Black & $(10.32)^{* * *}$ & & & $(0.01)$ \\
& 14.91 & 12.15 & 0.01 & 0.31 \\
& $(9.73)$ & $(15.60)$ & $(0.01)$ & $(0.19)$ \\
& 328.63 & -365.56 & 0.32 & -0.06
\end{tabular}




\begin{tabular}{lcccc} 
& $(171.73)$ & $(337.49)$ & $(0.15)$ & $(0.17)$ \\
Constant & -865.74 & -19.34 & -0.76 & -0.48 \\
& $(583.66)$ & $(810.46)$ & $(0.55)$ & $(0.43)$ \\
\hline$R^{2}$ & 0.78 & 0.43 & 0.34 & 0.26 \\
$N$ & 23 & 23 & 38 & 91 \\
\hline \multicolumn{5}{r}{$* p<0.1 ; * * p<0.05 ; * * * p<0.01$} \\
All regressions include Wave fixed effect.
\end{tabular}

In Table 7, we separate the subjects according to their case management attendance in the second month. Column 1 (Present 1st mo only) includes subjects that only attended case management during the first month of competition; these subjects remained at the shelter for an average of 4 days after the end of the first month competition. Columns 2 and 3 (Present both months) include subjects that attended case management in both months of the competition.

The first two columns (OLS M1 saving) of Table 7 compare the effect of competition across these two groups of subjects. The Competition dummy is only significant in the first column, suggesting that the subjects who increased their savings rate in response to the competition were also the ones who left the shelter after the first month of competition. However, comparing the coefficient on M1 income across the two columns suggests that these two groups of subjects may have been saving at different rates even at the baseline. Subjects who left the shelter after the first month were saving $\$ 61$ of every $\$ 100$ earned, while subjects who continued with case management were saving at a lower rate of $\$ 42$ for every $\$ 100$ earned.

Table 7 Relationship between $1^{\text {st }}$ and $2^{\text {nd }}$ month competition

\begin{tabular}{lccc}
\hline & Present 1st mo only & \multicolumn{2}{c}{ Present both months } \\
\hline OLS M1 saving & OLS M1 saving & $\begin{array}{c}\text { OLS M2 } \\
\text { saving }\end{array}$ \\
\hline Competition & 130.63 & 35.06 & -227.47 \\
Pre income & $(70.99)^{*}$ & $(50.18)$ & $(198.04)$ \\
Pre saving & -12.53 & -2.15 & \\
& $(43.42)$ & $(30.64)$ & \\
M1 income & 24.69 & 20.85 & \\
& $(40.71)$ & $(29.41)$ & \\
& 60.92 & 41.93 & \\
& $(25.24)^{* *}$ & $(10.51)^{* * *}$ &
\end{tabular}


M1 saving $\mathrm{x}$

\begin{tabular}{|c|c|c|c|}
\hline Age & $\begin{array}{r}0.10 \\
(2.01)\end{array}$ & $\begin{array}{l}2.61 \\
(2.08)\end{array}$ & $\begin{array}{l}16.67 \\
(9.80) *\end{array}$ \\
\hline Single & $\begin{array}{r}-74.42 \\
(76.08)\end{array}$ & $\begin{array}{l}-2.61 \\
(62.24)\end{array}$ & $\begin{array}{l}162.71 \\
(167.11)\end{array}$ \\
\hline Black & $\begin{array}{r}120.11 \\
(75.37)\end{array}$ & $\begin{array}{r}112.26 \\
(79.97)\end{array}$ & $\begin{array}{c}-245.09 \\
(129.40) *\end{array}$ \\
\hline Constant & $\begin{array}{r}-9.47 \\
(150.09) \\
\end{array}$ & $\begin{array}{r}-131.90 \\
(101.63)\end{array}$ & $\begin{array}{r}-398.86 \\
(384.52) \\
\end{array}$ \\
\hline$R^{2}$ & 0.47 & 0.72 & 0.32 \\
\hline$N$ & 55 & 36 & 36 \\
\hline
\end{tabular}

The results from OLS M1 saving in Table 7 confirm that 1) subjects saving a high fraction of their income are more likely to leave the shelter and 2) this early departure is indeed the reason for the ineffectiveness of the second month of competition. Our data does not allow us to determine subjects' motivation for leaving, however, we believe that two different behavioral mechanisms may be driving this behavior. The first mechanism is ego-depletion: among subjects earning very little income, the effort it takes to save at high rates may be so costly that it depletes subjects' willpower. Subjects then become impatient and are unwilling to make further investments for the future. The second mechanism is self-selection: subjects that are especially motivated to leave the shelter will attempt to save as much as they can in a short period of time.

We last check whether subjects were behaving strategically, given their knowledge that the competition would be repeated for a second month. There are several ways in which subjects could attempt to game the system. For example, a subject might withhold his first month savings to declare in the second month along with his second month savings. This strategy would afford the subject a greater chance of winning the second month competition without necessitating any change in spending habits in the first or second month. It is also possible for subjects to form partnerships. Each party could take a turn subsidizing the other party's monthly expenses. This would allow the subsidized partner to save his entire income and thus increase his chances of winning the 
competition. ${ }^{34}$ Both of these scenarios could result in savings rates within the competition group that appear higher than those in the control group, but these rates would not reflect any real change in savings habits because the same amount of savings would simply be shifted from one month to another.

The last column of Table 7 provides a formal test of the relationship between first and second month savings for the subjects that remained at the shelter. While the relationship between the amounts saved in the first (M1 Saving) and second months (M2 Saving) is likely to be positive in the control group, this relationship would be negative if the competition had induced subjects to pool their savings across the two months (as described in the two scenarios above). This conjecture is further supported by the statistical insignificance of the coefficient on M1 Saving $x$ Competition, which implies that subject were not shifting savings from one month to another. ${ }^{35}$

\section{Conclusion}

Our study finds that one-month savings competitions do increase savings rates among working homeless individuals who are preparing to transition out of a shelter. Since savings rates are computed as the ratio of savings to net income (income less work expenditures), the subjects in the competition group could have under-reported their income and over-reported their work expenditures to win the competition. However, subjects did neither. It appears that clients were trying to win the competition simply by saving more; however, without the ability to increase income to meet this desire to save, their only choice was to decrease all expenditures.

Despite the fact that subjects had another chance to win monetary prizes in the second month, the saving competition had no effect. The increase in savings may not have been sustainable in the second month, as it was driven by extremely low expenditures. Our results are consistent with habit formation studies by Charness and Gneezy (2009) and Acland and Levy (2010). While Charness and Gneezy find that

\footnotetext{
${ }^{34}$ Given that the subjects who responded to the first month of competition had left the shelter by the second month, it is unlikely that the partnership scenario could take place.

${ }^{35}$ We cannot preclude all possibilities of strategically gaming the system. However, partnerships are unlikely given the lack of trust among clients at the shelter with regard to money. After departing from the shelter, clients are very difficult to track. Without a credible threat of punishment for defectors, cooperation cannot be sustained.
} 
monetary incentives help people form a habit of going to the gym regularly, Acland and Levy find that the positive impact of monetary incentives does not sustain regular gym attendance in the long run. Furthermore, Iriberri, Apesteguia, and Funk (2010) find that sending reminders to return library books is successful in the first, but not the second month.

We also find that many of the individuals who increased their savings rate in response to the competition left the shelter after the first month. This is consistent with two very different explanations: ego depletion and self-selection. The first suggests that clients are exhausted by the effort of saving at high rates and stop investing further effort in shelter programs. The second suggests those clients who are motivated to increase their savings in order to win the competition are also those who want to exit the shelter earlier. Our data does not tell us which explanation is more plausible. We leave this important question to future research.

Looking more broadly across the range of behavior, which describes participation of the working homeless in shelter support services, we find that the only effect of the competition is to increase the savings rate of subjects reporting an income. The competition does not impact: the propensity to earn, the amount of income reported, nor attendance of case management meetings. Given that the best predictor of savings is income and that nearly 50\% of clients did not report any income, interventions that encourage attendance at case management meetings and help clients to retain and progress at their jobs may be more effective in transitioning the working homeless into permanent housing. 


\section{References}

Acland, Dan and Levy, Matthew, 2010, Habit Formation and Naivete in Gym Attendance: Evidence from a Field Experiment University of California Berkeley Working Paper.

Agarwal, Sumit, Skiba, Paige Marta and Tobacman, Jeremy, 2009. Payday Loans and Credit Cards: New Liquidity and Credit Scoring Puzzles? American Economic Review, 99(2), 412-417.

Ameriks, John, Caplin, Andrew, Leahy, John and Tyler, Tom, 2007. Measuring SelfControl Problems. American Economic Review, 97(3), 966-972.

Angeletos, George-Marios, Laibson, David, Repetto, Andrea, Tobacman, Jeremy and Weinberg, Stephen, 2001. The Hyperbolic Consumption Model: Calibration, Simulation, and Empirical Evaluation. Journal of Economic Perspectives, 15(3), 47-68.

Ashraf, Nava, Karlan, Dean S. and Yin, Wesley, 2006. Tying Odysseus to the Mast: Evidence from a Commitment Savings Product in the Philippines. Quarterly Journal of Economics 121(2), 635-672.

Ausubel, Lawrence M., 1999. Adverse Selection in the Credit Card Market. University of Maryland Working Paper.

Bandiera, Oriana, Barankay, Iwan and Rasul, Imran, 2008, Social Incentives in the Workplace. London School of Economics and Political Science.

Brocas, Isabelle and Carrillo, Juan D., 2001. Rush and Procrastination under Hyperbolic Discounting and Interdependent Activities. Journal of Risk and Uncertainty, 22(2), 141-164.

Brown, Alexander L., Camerer, Colin F. and Chua, Zhikang Eric, 2009. Learning and Visceral Temptation in Dynamic Savings Experiments. Quarterly Journal of Economics, 124(1), 197-231.

Bryan, Gharad, Karlan, Dean and Nelsonz, Scott 2010, Commitment Device. Yale University Working Paper.

Burks, Stephen V., Carpenter, Jeffrey P., Goette, Lorenz and Rustichini, Aldo, 2009. Cognitive Skills Affect Economic Preferences, Strategic Behavior, and Job Attachment. PNAS, 106(19), 7745-7750.

Carrell, Scott and Zinman, Jonathan, 2008. In Harm’s Way?: Payday Loan Access and Military Personnel Performance, UC Davis.

Charness, Gary and Gneezy, Uri, 2009. Incentives to Exercise. Econometrica, 77(3), 909931.

Destin, Mesmin and Oyserman, Daphna, 2010. Incentivizing Education: Seeing Schoolwork as an Investment, Not a Chore. Journal of Experimental Social Psychology, 46(5), 846-849.

Eckel, Catherine, Johnson, Cathleen and Montmarquette, Claude, 2005, Saving Decisions of the Working Poor: Short-and Long-Term Horizons. In: Glenn W. Harrison and John A. List (Eds.), Field Experiments in Economics. JAI Press, Greenwich and London. 
Falk, Armin and Ichino, Andrea, 2006. Clean Evidence on Peer Effects. Journal of Labor Economics, 24(1), 39-57.

Gross, David B. and Souleles, Nicholas S., 2002. Do Liquidity Constraints and Interest Rates Matter for Consumer Behavior? Evidence from Credit Card Data. Quarterly Journal of Economics, 117(1), 149-185.

Harbring, C., \& Irlenbusch, B., 2008. How Many Winners are Good to Have? On

Tournaments with Sabotage. Journal of Economic Behavior and Organization, 65, 682702.

Harrison, Glenn W., Lau, Morten I. and Williams, Melonie B., 2002. Estimating Individual Discount Rates in Denmark: A Field Experiment. American economic review, 92(5), 1606-1617.

Hausman, Jerry, 1979. Individual Discount Rates and the Purchase and Utilization of Energy-using Durables. Bell Journal of Economics, 10(1), 33-54.

Iriberri, Nagore, Apesteguia, Jose, and Funk, Patricia, 2010. Promoting Rule Compliance in Daily-Life: Evidence from a Randomized Field Experiment in the Public Libraries of Barcelona. University Pompeu Fabra Working Paper.

Karlan, Dean, 2010. Helping the Poor Save More. Stanford Social Investment Review(Winter), 48-53.

Karlan, Dean and Zinman, Jonathan, 2009. Expanding Credit Access: Using Randomized Supply Decisions to Estimate the Impacts. Review of Financial Studies, 23(1), 433-464.

Kremer, Michael, Miguel, Edward and Thornton, Rebecca, 2009. Incentives to Learn. Review of Economics and Statistics, 91(3), 437-456.

Laibson, David, 1997. Golden Eggs and Hyperbolic Discounting. Quarterly Journal of Economics, 112(2), 443-477.

Lawrance, Emily C., 1991. Poverty and the Rate of Time Preference: Evidence from Panel Data. Journal of Political Economy, 99(1), 54-77.

McKernan, Signe-Mary and Sherraden, Michael, 2008. Asset Building and Low-Income Families. Urban Institute, Washington DC.

Meier, Stephan and Sprenger, Charles, 2010. Present-biased Preferences and Credit Card Borrowing. American Economic Journal: Applied Economics, 2(1), 193-210.

Moldovanu, Benny and Sela, Aner, 2001. The Optimal Allocation of Prizes in Contests. American Economic Review, 91(3), 542-558.

Müller, Wieland and Schotter, Andrew, 2010. Workaholics and Dropouts in Optimal Organizations. Journal of the European Economic Association, 8(4), 717-743

National Coalition for the Homeless. Who Is Homeless? Published by the National Coalition for the Homeless, July 2009. http://nationalhomeless.org/factsheets/who.html, Accessed May 2012.

National Alliance to End Homelessness. The State of Homelessness in America Report Suggests Risk of Homelessness Persists for Many American Families. National Alliance to End Homeless Press Release, 17 January 2012. http://www.endhomelessness.org/content/article/detail/4358, Accessed May 2012.

Neumark-Sztainer, Dianne, Wall, Melanie, Mary, Story, and, Standish, Amber R., 2012. Dieting and Unhealthy Weight Control Behaviors During Adolescence: Associations with 10-Year Changes in Body Mass Index. Journal of Adolescent Health, 50(1), 80-86. 
Nielsen, Uffe, 2001. Poverty and Attitudes towards Time and Risk: Experimental Evidence from Madagascar. Royal Veterinary and Agricultural University of Denmark Working Paper.

O'Donoghue, Ted and Rabin, Matthew, 1999. Doing It Now or Later. American Economic Review, 89(1), 103-124.

O'Donoghue, Ted and Rabin, Matthew, 2001. Choice and Procrastination. Quarterly Journal of Economics, 116(1), 121-160.

O’Flaherty, Brendan, 2009a, Homelessness as Bad Luck: Implications for Research and Policy. Columbia University Working Paper.

O’Flaherty, Brendan, 2009b, Managing Homeless Shelters. Columbia University Working Paper.

O’Flaherty, Brendan, 2009c, Homeless in the United States. Columbia University Working Paper.

Ozdenoren, Emre, Salant, Stephen and Silverman, Dan, Forthcoming. Willpower and the Optimal Control of Visceral Urges. Journal of the European Economic Association.

Pender, John L., 1996. Discount Rates and Credit Markets: Theory and Evidence from Rural India. Journal of Development Economics, 50, 257-296.

Phelps, E. S. and Pollak, R. A., 1968. On Second-Best National Saving and GameEquilibrium Growth. Review of Economic Studies, 35(2), 185-199.

Schotter, Andrew and Weigelt, Keith, 1992. Asymmetric Tournaments, Equal Opportunity Laws, and Affirmative Action: Some Experimental Results. Quarterly Journal of Economics, 107(2), 511-539.

Sheremeta, Roman, 2010. Perfect-Substitutes, Best-Shot, and Weakest-Link Contests between Groups. Chapman University Working Paper.

Skiba, Paige Marta and Tobacman, Jeremy, 2008. Payday Loans, Uncertainty, and Discounting: Explaining Patterns of Borrowing, Repayment, and Default. Vanderbilt Law School Working Paper.

Strotz, R. H., 1956. Myopia and Inconsistency in Dynamic Utility Maximization. Review of Economic Studies, 23, 165-180.

Tanaka, Tomomi, Camerer, Colin F. and Nguyen, Quang, 2010. Risk and Time Preferences: Linking Experimental and Household Survey Data from Vietnam. American Economic Review, 100(1), 557-571.

Thaler, R. H. and Shefrin, H. M., 1981. An Economic Theory of Self-Control. Journal of Political Economy, 89(2), 392-406.

Tran, Ngoc-Anh and Zeckhauser, Richard, 2008. Rank as an Incentive. Harvard University Working Paper.

Yesuf, Mahmud, 2004. Risk, Time, and Land Management under Market Imperfections: Applications to Ethiopia. Göteborg University Working Paper.

Zinman, Jonathan, 2010. Restricting Consumer Credit Access: Household survey evidence on Effects around the Oregon Rate Cap. Journal of Banking and Finance, 34(3), 546-556. 


\section{Appendix}

Figure A1 Pre recruitment compliance rate and financial reports in Wave 0

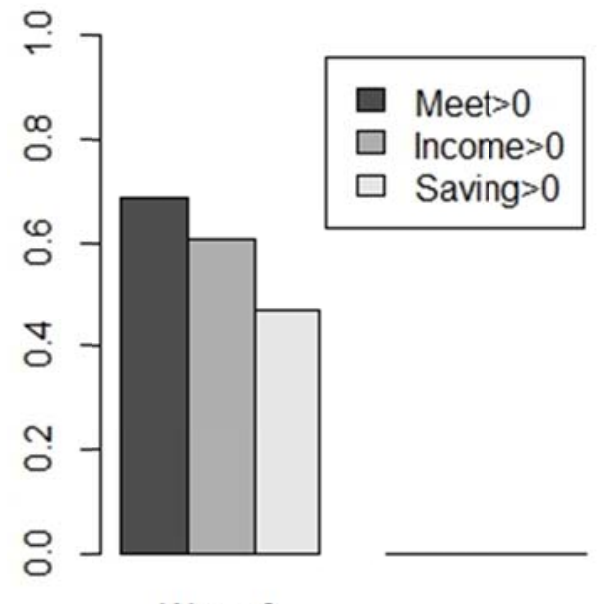

Wave 0

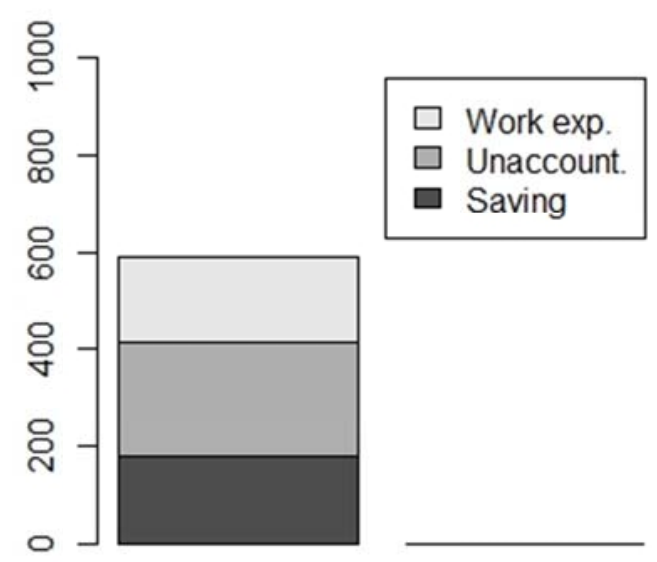

Wave 0

Figure A2 Pre recruitment, first month (M1), and second month (M2)

Compliance rates

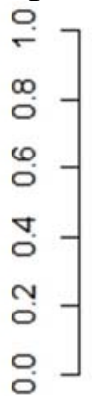

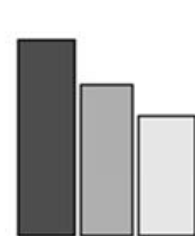

Base Pre

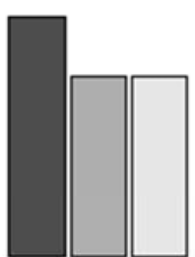

Base M1

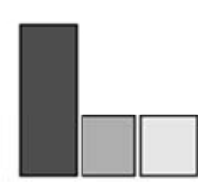

Base M2

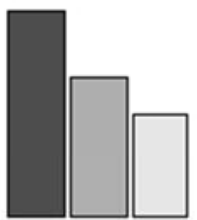

Comp Pre

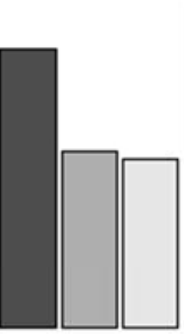

Comp M1

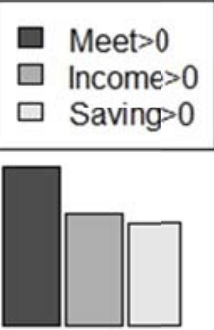

Comp M2

Financial reports in Wave1 (5\% trimmed mean)
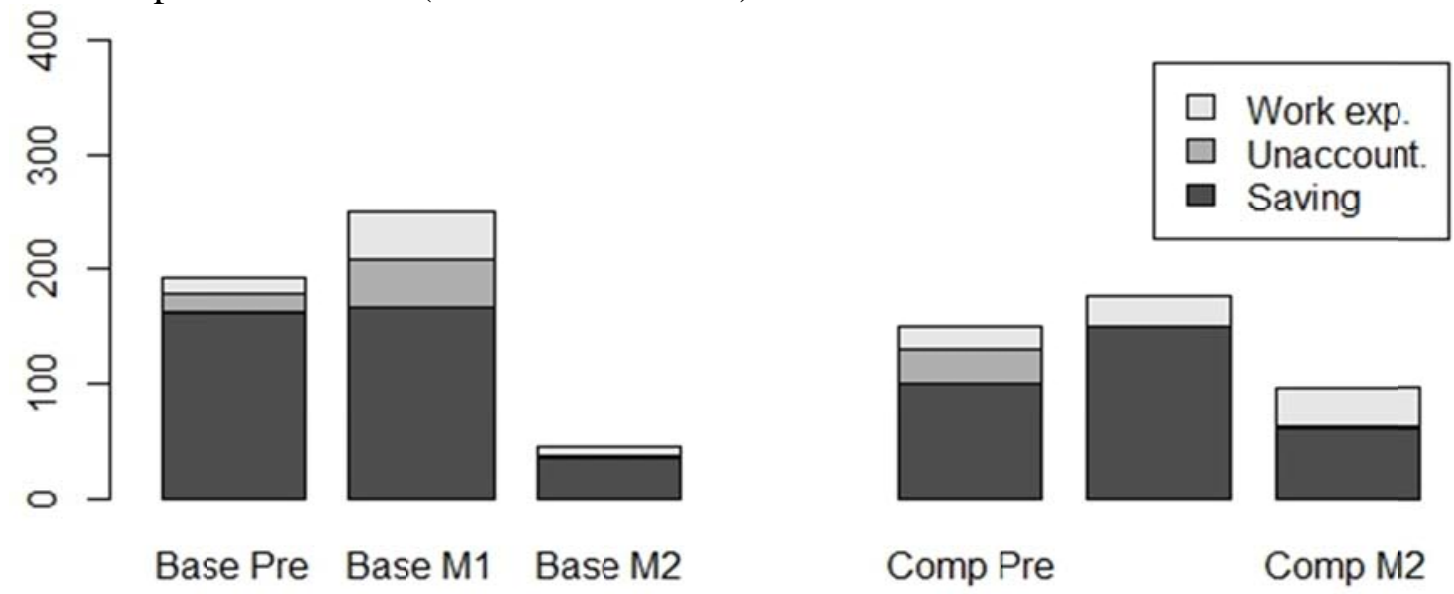
Table A1 First month finances, Wave 1-3 (Table 4) with all control variables

\begin{tabular}{|c|c|c|c|c|c|}
\hline & Model 1 & Model 2 & Model 3 & Model 4 & Model 5 \\
\hline & Income & Savings & Savings & Work Exp. & Work Exp. \\
\hline \multirow[t]{2}{*}{ Competition } & -5.37 & 85.48 & 89.01 & -38.30 & -37.74 \\
\hline & (65.31) & $(46.15) *$ & $(31.80)^{* * *}$ & $(24.72)$ & $(21.85)^{*}$ \\
\hline \multirow[t]{2}{*}{ M1 income } & & & 0.66 & & 0.10 \\
\hline & & & $(0.09)^{* * *}$ & & $(0.06)$ \\
\hline \multirow[t]{2}{*}{ Pre meet } & 62.25 & 25.44 & -15.44 & 20.58 & 14.05 \\
\hline & $(68.65)$ & (76.59) & (59.32) & (20.89) & (19.96) \\
\hline \multirow[t]{2}{*}{ Pre income } & 56.77 & 21.55 & -15.74 & 17.60 & 11.65 \\
\hline & (49.51) & (20.77) & (39.41) & $(4.51)^{* * *}$ & (7.30) \\
\hline \multirow[t]{2}{*}{ Pre saving } & -57.77 & -7.10 & 30.84 & -23.44 & -17.38 \\
\hline & $(46.84)$ & (23.83) & (32.60) & $(5.66)^{* * *}$ & $(8.07)^{* *}$ \\
\hline \multirow[t]{2}{*}{ Days L1-2 } & 0.62 & 0.77 & 0.36 & -0.07 & -0.13 \\
\hline & $(0.75)$ & $(0.58)$ & $(0.43)$ & $(0.14)$ & $(0.15)$ \\
\hline \multirow[t]{2}{*}{ Days L3 } & -0.36 & -0.68 & -0.44 & 0.21 & 0.25 \\
\hline & $(0.83)$ & $(0.67)$ & $(0.34)$ & $(0.20)$ & $(0.16)$ \\
\hline \multirow[t]{2}{*}{ Age } & 11.75 & 7.25 & -0.47 & 1.60 & 0.36 \\
\hline & $(3.36)^{* * *}$ & $(2.77)^{* *}$ & (1.11) & $(0.64)^{* *}$ & $(0.70)$ \\
\hline \multirow[t]{2}{*}{ Female } & -1.09 & 47.88 & 48.59 & -8.19 & -8.08 \\
\hline & (65.78) & (50.83) & $(40.47)$ & (16.78) & (14.77) \\
\hline \multirow[t]{2}{*}{ Education } & -16.74 & 1.92 & 12.92 & -5.53 & -3.78 \\
\hline & (18.50) & (13.66) & $(7.21)^{*}$ & (5.95) & (4.61) \\
\hline \multirow[t]{2}{*}{ Single } & -78.49 & -115.45 & -63.90 & -17.80 & -9.58 \\
\hline & (70.57) & $(60.72)^{*}$ & (46.58) & (18.70) & (13.91) \\
\hline \multirow{2}{*}{$\begin{array}{l}\text { \# of } \\
\text { children }\end{array}$} & -18.21 & -18.47 & -6.51 & -3.97 & -2.06 \\
\hline & (22.95) & (19.73) & (12.51) & $(4.54)$ & $(3.80)$ \\
\hline \multirow[t]{2}{*}{ Black } & -61.89 & 74.16 & 114.81 & -32.39 & -25.90 \\
\hline & (68.24) & (74.39) & $(51.20)^{* *}$ & $(18.94)^{*}$ & $(14.80)^{*}$ \\
\hline \multirow[t]{2}{*}{ First time } & 56.03 & 74.60 & 37.80 & -15.96 & -21.84 \\
\hline & (81.09) & (71.34) & (37.68) & (18.68) & (19.51) \\
\hline \multirow{2}{*}{$\begin{array}{l}\text { Mo } \\
\text { homeless }\end{array}$} & 0.48 & 1.01 & 0.69 & -0.28 & -0.33 \\
\hline & $(2.16)$ & $(1.65)$ & $(0.96)$ & $(0.61)$ & $(0.51)$ \\
\hline \multirow[t]{2}{*}{ Wave 3} & 3.54 & -45.96 & -48.29 & 17.27 & 16.90 \\
\hline & (85.29) & (77.86) & (50.43) & (31.03) & (26.84) \\
\hline \multirow[t]{2}{*}{ Wave 4} & 147.88 & 51.15 & -45.97 & 9.43 & -6.07 \\
\hline & (111.80) & (99.64) & (49.12) & (19.80) & (22.36) \\
\hline \multirow[t]{2}{*}{ Constant } & -101.90 & -250.86 & -183.93 & 72.64 & 83.32 \\
\hline & $(276.94)$ & (190.91) & $(112.62)$ & $(97.15)$ & $(87.12)$ \\
\hline$R^{2}$ & 0.27 & 0.25 & 0.72 & 0.20 & 0.32 \\
\hline$N$ & 116 & 116 & 116 & 116 & 116 \\
\hline
\end{tabular}

${ }^{*} p<0.1 ; * * p<0.05 ; * * * p<0.01$

All regressions include Wave fixed effect 
Table A2 Effect of competition on $1^{\text {st }}$ month behavior: Wave 1-3 (Table 5) with all control variables

\begin{tabular}{|c|c|c|c|c|}
\hline & $\begin{array}{c}\text { Model } 1 \\
\text { M1 Saving | M1 Income }>0\end{array}$ & $\begin{array}{c}\text { Model } 2 \\
\text { M1 Income | M1 } \\
\text { Income }>0\end{array}$ & $\begin{array}{c}\text { Model } 3 \\
\text { Pr(M1 Income }>0 \mid \\
\text { M1 meeting }>0)\end{array}$ & $\begin{array}{l}\text { Model } 4 \\
\text { M1 Meeting }\end{array}$ \\
\hline Competition & $\begin{array}{l}141.89 \\
(56.58)^{* *}\end{array}$ & $\begin{array}{c}-56.39 \\
(105.45)\end{array}$ & $\begin{array}{c}0.09 \\
(0.11)\end{array}$ & $\begin{array}{c}0.06 \\
(0.19)\end{array}$ \\
\hline M1 meet & $\begin{array}{c}35.65 \\
(55.47)\end{array}$ & $\begin{array}{l}126.47 \\
(80.05)\end{array}$ & $\begin{array}{c}0.14 \\
(0.11)\end{array}$ & \\
\hline M1 income & $\begin{array}{l}69.72 \\
(12.39)^{* * *}\end{array}$ & & & \\
\hline Pre meet & $\begin{array}{c}21.31 \\
(86.44)\end{array}$ & $\begin{array}{c}107.48 \\
(106.11)\end{array}$ & $\begin{array}{c}0.11 \\
(0.13)\end{array}$ & $\begin{array}{c}0.00 \\
(0.18)\end{array}$ \\
\hline Pre income & $\begin{array}{l}-51.12 \\
(37.13)\end{array}$ & $\begin{array}{c}19.33 \\
(56.64)\end{array}$ & $\begin{array}{l}-0.01 \\
(0.05)\end{array}$ & $\begin{array}{l}0.18 \\
(0.07)^{* * *}\end{array}$ \\
\hline Pre saving & $\begin{array}{c}59.26 \\
(32.10)^{*}\end{array}$ & $\begin{array}{c}6.54 \\
(49.12)\end{array}$ & $\begin{array}{l}-0.00 \\
(0.05)\end{array}$ & $\begin{array}{l}-0.18 \\
(0.07)^{* *}\end{array}$ \\
\hline Days L1-2 & $\begin{array}{c}0.24 \\
(0.46)\end{array}$ & $\begin{array}{c}0.01 \\
(1.22)\end{array}$ & $\begin{array}{c}0.00 \\
(0.00)\end{array}$ & $\begin{array}{c}0.00 \\
(0.00)\end{array}$ \\
\hline Days L3 & $\begin{array}{l}-0.34 \\
(0.74)\end{array}$ & $\begin{array}{c}0.14 \\
(1.38)\end{array}$ & $\begin{array}{l}-0.00 \\
(0.00)\end{array}$ & $\begin{array}{l}-0.00 \\
(0.00)\end{array}$ \\
\hline Age & $\begin{array}{c}1.05 \\
(2.69)\end{array}$ & $\begin{array}{l}10.69 \\
(5.33)^{*}\end{array}$ & $\begin{array}{c}0.01 \\
(0.01)^{*}\end{array}$ & $\begin{array}{c}0.01 \\
(0.01)\end{array}$ \\
\hline Female & $\begin{array}{l}-11.35 \\
(70.22)\end{array}$ & $\begin{array}{l}-181.26 \\
(131.38)\end{array}$ & $\begin{array}{l}-0.10 \\
(0.14)\end{array}$ & $\begin{array}{c}0.32 \\
(0.21)\end{array}$ \\
\hline Education & $\begin{array}{c}12.62 \\
(12.60)\end{array}$ & $\begin{array}{l}-25.33 \\
(22.09)\end{array}$ & $\begin{array}{l}-0.01 \\
(0.02)\end{array}$ & $\begin{array}{c}0.04 \\
(0.05)\end{array}$ \\
\hline Single & $\begin{array}{l}-41.97 \\
(50.80)\end{array}$ & $\begin{array}{l}-170.97 \\
(105.22)\end{array}$ & $\begin{array}{l}-0.01 \\
(0.13)\end{array}$ & $\begin{array}{l}-0.11 \\
(0.20)\end{array}$ \\
\hline \# of children & $\begin{array}{c}19.81 \\
(29.80)\end{array}$ & $\begin{array}{l}-52.27 \\
(43.08)\end{array}$ & $\begin{array}{c}0.00 \\
(0.05)\end{array}$ & $\begin{array}{c}0.04 \\
(0.06)\end{array}$ \\
\hline Black & $\begin{array}{c}193.40 \\
(106.23)^{*}\end{array}$ & $\begin{array}{l}-116.27 \\
(106.05)\end{array}$ & $\begin{array}{c}0.08 \\
(0.14)\end{array}$ & $\begin{array}{l}-0.19 \\
(0.18)\end{array}$ \\
\hline First time & $\begin{array}{c}66.34 \\
(65.59)\end{array}$ & $\begin{array}{c}127.54 \\
(125.22)\end{array}$ & $\begin{array}{l}-0.02 \\
(0.13)\end{array}$ & $\begin{array}{c}0.08 \\
(0.20)\end{array}$ \\
\hline Mo homeless & $\begin{array}{c}0.13 \\
(1.50)\end{array}$ & $\begin{array}{c}2.81 \\
(2.92)\end{array}$ & $\begin{array}{c}0.00 \\
(0.01)\end{array}$ & $\begin{array}{c}0.00 \\
(0.01)\end{array}$ \\
\hline Wave 3 & $\begin{array}{l}-63.42 \\
(85.08)\end{array}$ & $\begin{array}{c}-8.07 \\
(142.73)\end{array}$ & $\begin{array}{l}-0.03 \\
(0.15)\end{array}$ & $\begin{array}{c}0.08 \\
(0.25)\end{array}$ \\
\hline Wave 4 & $\begin{array}{l}-61.88 \\
(80.75)\end{array}$ & $\begin{array}{c}236.87 \\
(162.00)\end{array}$ & $\begin{array}{c}0.08 \\
(0.14)\end{array}$ & $\begin{array}{c}0.18 \\
(0.25)\end{array}$ \\
\hline Constant & $\begin{array}{l}-399.14 \\
(240.05)\end{array}$ & $\begin{array}{c}48.16 \\
(460.71)\end{array}$ & $\begin{array}{l}-0.11 \\
(0.48)\end{array}$ & $\begin{array}{c}0.19 \\
(0.80)\end{array}$ \\
\hline$R^{2}$ & 0.75 & 0.39 & 0.16 & 0.16 \\
\hline$N$ & 59 & 59 & 88 & 116 \\
\hline
\end{tabular}


Table A3 Effect of competition on $1^{\text {st }}$ month behavior (Table 5), Wave 1-2 only

\begin{tabular}{|c|c|c|c|c|}
\hline & $\begin{array}{c}\text { Model } 1 \\
\text { M1 Saving | M1 } \\
\text { Income }>0\end{array}$ & $\begin{array}{c}\text { Model } 2 \\
\text { M1 Income | M1 } \\
\text { Income>0 }\end{array}$ & $\begin{array}{c}\text { Model } 3 \\
\text { Pr(M1 Income }>0 \mid \\
\text { M1 meeting }>0)\end{array}$ & $\begin{array}{l}\text { Model } 4 \\
\text { M1 Meeting }\end{array}$ \\
\hline Competition & $\begin{array}{l}131.56 \\
(70.20)^{*}\end{array}$ & $\begin{array}{r}-129.61 \\
(98.48)\end{array}$ & $\begin{array}{l}-0.01 \\
(0.11)\end{array}$ & $\begin{array}{l}-0.16 \\
(0.20)\end{array}$ \\
\hline Pre income & $\begin{array}{l}-29.91 \\
(13.33)^{* *}\end{array}$ & $\begin{array}{c}44.27 \\
(44.60)\end{array}$ & $\begin{array}{c}0.02 \\
(0.03)\end{array}$ & $\begin{array}{l}0.21 \\
(0.07)^{* * *}\end{array}$ \\
\hline Pre saving & $\begin{array}{l}46.77 \\
(15.16)^{* * *}\end{array}$ & $\begin{array}{l}-29.18 \\
(46.47)\end{array}$ & $\begin{array}{l}-0.01 \\
(0.04)\end{array}$ & $\begin{array}{l}-0.21 \\
(0.09)^{* *}\end{array}$ \\
\hline M1 meeting & $\begin{array}{l}125.01 \\
(60.67)^{* *}\end{array}$ & $\begin{array}{c}48.81 \\
(71.16)\end{array}$ & $\begin{array}{c}0.11 \\
(0.10)\end{array}$ & \\
\hline M1 income & $\begin{array}{l}44.88 \\
(13.47)^{* * *}\end{array}$ & & & \\
\hline Age & $\begin{array}{c}1.05 \\
(2.15)\end{array}$ & $\begin{array}{l}11.69 \\
(3.97)^{* * *}\end{array}$ & $\begin{array}{l}0.02 \\
(0.01)^{* * *}\end{array}$ & $\begin{array}{c}0.00 \\
(0.01)\end{array}$ \\
\hline Single & $\begin{array}{c}-124.07 \\
(75.55)\end{array}$ & $\begin{array}{l}-62.90 \\
(79.86)\end{array}$ & $\begin{array}{c}0.04 \\
(0.14)\end{array}$ & $\begin{array}{l}-0.32 \\
(0.21)\end{array}$ \\
\hline Black & $\begin{array}{l}289.58 \\
(118.32)^{* *}\end{array}$ & $\begin{array}{c}-6.29 \\
(98.82)\end{array}$ & $\begin{array}{c}0.20 \\
(0.14)\end{array}$ & $\begin{array}{l}-0.38 \\
(0.20)^{*}\end{array}$ \\
\hline Constant & $\begin{array}{l}-250.20 \\
(133.67)^{*}\end{array}$ & $\begin{array}{c}-99.87 \\
(263.50)\end{array}$ & $\begin{array}{l}-0.25 \\
(0.30)\end{array}$ & $\begin{array}{l}1.56 \\
(0.50)^{* * *}\end{array}$ \\
\hline$R^{2}$ & 0.57 & 0.37 & 0.20 & 0.14 \\
\hline$N$ & 44 & 44 & 68 & 91 \\
\hline
\end{tabular}




\section{Experimental Appendix}

The time discounting experiment is administered face to face by an experimenter. ${ }^{36}$ All experimenters read from the script below and were given decision trees to determine the sequence of questions. Figure A3 illustrate the left branch of this decision tree for question 1 to 8 . The decision trees were not shown to the subjects.

Each subject makes 31 decisions between a smaller current payoff and a larger future payoff. ${ }^{37}$ Subsequent questions are determined by the choices made in preceding questions. 24 of the 31 questions involve binary choices between receiving 10 dollars today or larger rewards on later days. The delayed rewards vary from $\$ 12$ to $\$ 30$ and the time delay varies from one day to 127 days. 7 of the 31 questions asked subjects whether they would like to receive 10 dollars tomorrow or 30 dollars at a later date.

The following questions are examples from the actual experiment. The full experimental instructions are given below Figure A3.

Question 1: Do you want to receive A) \$10 today, or B) \$30 in 64 days? This first question establishes a reference point for subsequent questions. Suppose a subject has chosen A in Question 1, then the second question would be: "Do you want to receive A) \$10 today, or B) \$30 in 32 days?” If the subject has chosen B in Question 1, then the second question would be: “Do you want to receive A) \$10 today, or B) \$30 in 96 days?”

After the subject completes the questionnaire, an experimenter puts thirty-one numbered balls in a bingo cage and let the subject to draw one ball to determine the question that would be implemented for experimental payment. For example, if ball l was drawn, and the subject has chosen A in Question 1, he will receive \$10 on the day of the experiment. If he has chosen $\mathrm{B}$, he will receive $\$ 30$ in 64 days.

The experimenter puts the reward (money order) in an envelope with a unique ID and the date the subject is to receive the money on the envelope and then seals the envelope in front of him. The envelope is kept in a security box in the case manager's

\footnotetext{
36 The local author or research assistants were the experimenters.

${ }^{37}$ For the first 8 subjects, we asked only 2 series of questions, i.e., 1) whether the subject prefers receiving $\$ 10$ today or $\$ 30$ days in the future, and 2) whether the subject prefers receiving $\$ 10$ tomorrow or $\$ 30$ days in the future. The maximum days of waiting was set at 63 days and 64 days in series 1 and 2, respectively. However, it quickly became evident that many subjects were willing to wait up to the maximum time and hence we cannot obtain the switching points for these individuals. The modified design is described here.
} 
office. The subjects are free to pick up the envelope any time after the appointed date. A client can leave the shelter and then return to pick up his payment.

Figure A3 Decision tree for time discounting experiment

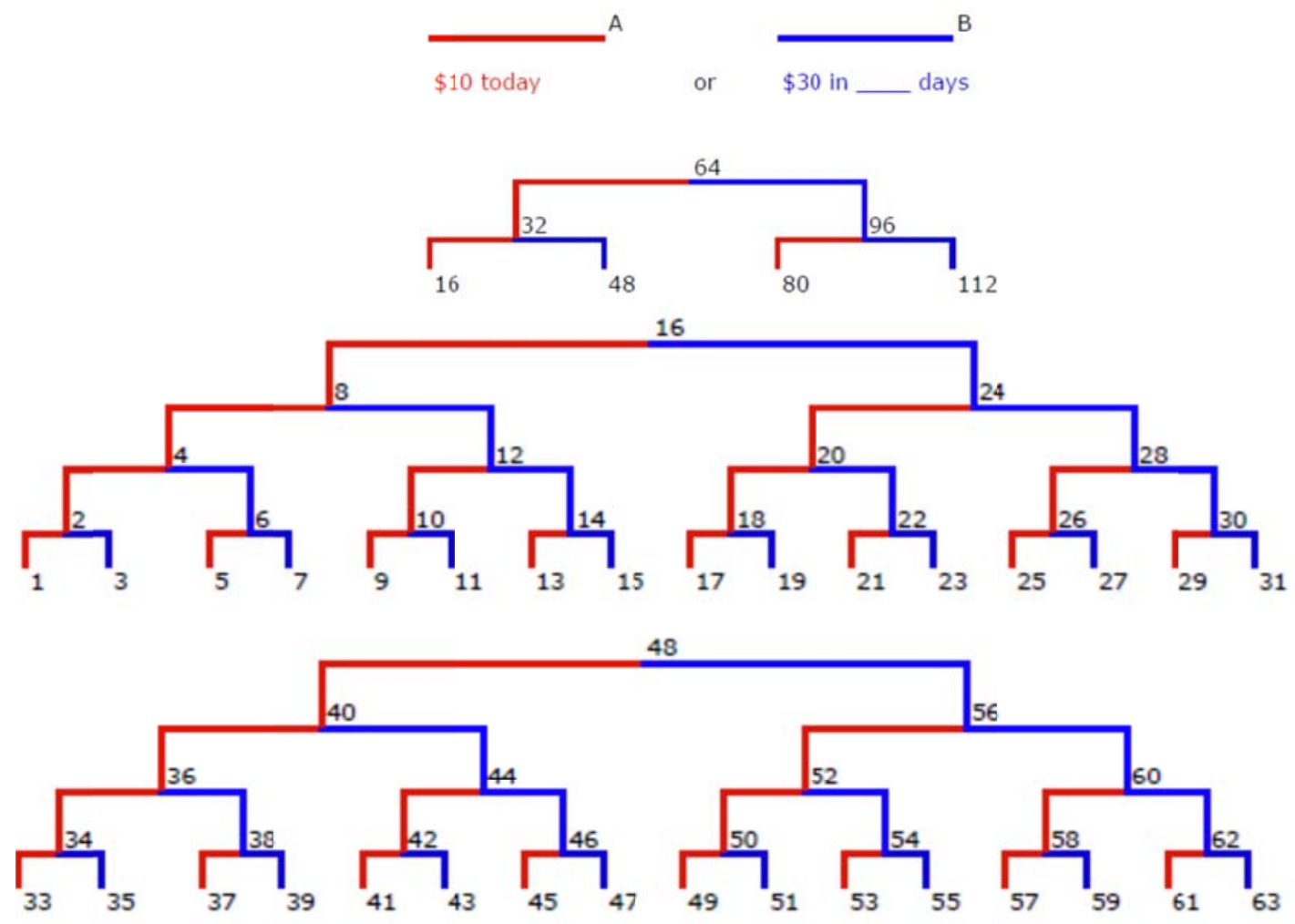

\section{A.1 Time Discount Experiment Script to be Read by Experimenter}

\section{Instruction}

You will receive money today or sometime in the future, depending on the choices you make in the following 31 questions. After you make 31 decisions, I will put 31 balls in a bingo cage and let you draw one ball to determine which question will be played for real money. For example, if the number 1 ball is drawn, and you have chosen A in Question 1 , you will receive $\$ 10$ today. If you have chosen $B$, you will receive $\$ 30$ in 64 days.

If you are receiving a money order on a later day, I will put it in an envelope, write down 
the your first name, the last 3 digits of your CASS ID number, and the date you are to receive the money order on an envelope, and seal the envelope in front of you.

Now we would like you to choose either A or B in each question.

Question 1: Do you want to receive A) \$10 today, or B) \$30 in 64 days?

Question 2: Do you want to receive A) \$10 today, or B) \$30 in ( _ ) days?

Question 3: Do you want to receive A) \$10 today, or B) \$30 in ( _ ) days?

Question 4: Do you want to receive A) \$10 today, or B) \$30 in ( _ ) days?

Question 5: Do you want to receive A) \$10 today, or B) \$30 in ( _ ) days?

Question 6: Do you want to receive A) \$10 today, or B) \$30 in ( _ ) days?

Question 7: Do you want to receive A) \$10 today, or B) \$30 in ( _ ) days?

Question 8: Do you want to receive A) \$10 today, or B) \$12 in 16 days?

Question 9: Do you want to receive A) \$10 today, or B) \$12 in ( _ ) days?

Question 10: Do you want to receive A) \$10 today, or B) \$12 in ( _ ) days?

Question 11: Do you want to receive A) \$10 today, or B) \$12 in ( _ ) days?

Question 12: Do you want to receive A) \$10 today, or B) \$12 in ( _ ) days?

Question 13: Do you want to receive A) \$10 tomorrow, or B) \$30 in 65 days?

Question 14: Do you want to receive A) \$10 tomorrow, or B) \$30 in ( ) days?

Question 15: Do you want to receive A) \$10 tomorrow, or B) \$30 in ( ～～days?

Question 16: Do you want to receive A) \$10 tomorrow, or B) \$30 in ( ～） days?

Question 17: Do you want to receive A) \$10 tomorrow, or B) \$30 in ( days?

Question 18: Do you want to receive A) \$10 tomorrow, or B) \$30 in ( ～～days?

Question 19: Do you want to receive A) \$10 tomorrow, or B) \$30 in ( ) days?

Question 20: Do you want to receive A) \$10 today, or B) \$18 in 32 days?

Question 21: Do you want to receive A) \$10 today, or B) \$18 in ( _ ) days? 
Question 22: Do you want to receive A) \$10 today, or B) \$18 in ( _ ) days?

Question 23: Do you want to receive A) \$10 today, or B) \$18 in ( _ ) days?

Question 24: Do you want to receive A) \$10 today, or B) \$18 in ( _ ) days?

Question 25: Do you want to receive A) \$10 today, or B) \$18 in ( _ ) days?

Question 26: Do you want to receive A) \$10 today, or B) \$24 in 32 days?

Question 27: Do you want to receive A) \$10 today, or B) \$24 in ( _ ) days?

Question 28: Do you want to receive A) \$10 today, or B) \$24 in ( _ ) days?

Question 29: Do you want to receive A) \$10 today, or B) \$24 in ( _ ) days?

Question 30: Do you want to receive A) \$10 today, or B) \$24 in ( _ ) days?

Question 31: Do you want to receive A) \$10 today, or B) \$24 in ( _ ) days?

Result

Number of the ball \#( )

Receive $\$(\quad)$ from on ___ (date) 


\section{A.2 Invitation Letter for the Saving Competition}

You are selected to participate in the "Savings Competition Program" for October of 2009.

The winner of this competition, who has saved the highest percentage of their income in the month, will receive $\mathbf{\$ 1 0 0}$. The second runner up will receive \$50. We will announce the winners on November 4.

Your work related expenses, child supports or debt payments will be taken into account when your case manager calculates your percentage of savings (as she always does).

In order to qualify for the competition, you need to meet with Joy twice in October, and report your income, expenditure and saving in both meetings. If you have any question, please ask your case manager or me.

(Contact information of experimenter here) 